\title{
Students' Cognitive Process In Problem Solving On Pattern Materials Reviewed From Math Anxiety
}

\author{
Muhammad Nanang Ferdiansyah ${ }^{1 *}$, Rooselyna Ekawati ${ }^{2}$ \\ 1,2 Universitas Negeri Surabaya \\ *muhammad.17030174032@mhs.unesa.ac.id
}

Received: December 2020; Accepted: December 2020; Published: January 2021

\begin{abstract}
This study uses a qualitative descriptive approach that aims to describe the cognitive processes of students in solving problems in the number pattern material in terms of the level of students' mathematics anxiety. The instruments used in this study were the mathematics ability test (TKM) to control subject selection, the mathematics anxiety questionnaire (AKM), the problem-solving test (TPM), and the interview guidelines. From several $8^{\text {th }}$ grade students, there are 21 male and 9 female students, one student was selected with a male student with high mathematical ability and high math anxiety and one male student with high mathematical ability and low math anxiety. The results showed that students with high and low math anxiety could solve problems, but there were differences in receiving, processing, storing, and recalling information. Students with low math anxiety check their answers again by processing the information in other ways, while students with high math anxiety do not. With the difference in the cognitive processes of students with math anxiety, teachers are advised to develop appropriate learning methods to reduce students' math anxiety, so that students can improve their thinking skills in mathematics at a higher level with low math anxiety.
\end{abstract}

Keywords: cognitive, mathematical ability, math anxiety, and problem solving.

How to Cite: Ferdiansyah, M. N. \& Ekawati, R. (2021). Students' Cognitive Process In Problem Solving On Pattern Materials Reviewed From Math Anxiety. Journal of Medives: Journal of Mathematics Education IKIP Veteran Semarang, 5(1), 137-150. 


\section{PENDAHULUAN}

Kemampuan berpikir siswa dapat dipicu dengan siswa melakukan kegiatan belajar setiap hari. Sedangkan kegiatan belajar selalu terkait dengan proses mental yang terjadi dalam otak (Ngilawajan, 2013). Berpikir adalah aktivitas mental yang ada pada pikiran siswa untuk memproses informasi yang diterima dan bisa diamati pada perilaku yang terlihat (isroil et al., 2017). Lailiyah, et al. (2015) juga mendefinisikan berpikir, yaitu proses kognitif yang melibatkan beberapa manipulasi pengetahuan sehingga menghasilkan perbuatan dalam menyelesaikan suatu permasalahan.

Jones (2006) mendefinisikan proses kognitif sebagai proses mental seseorang, dengan ikatan khusus serta pemikiran yang beranggapan bahwa pikiran mempunyai kondisi mental internal (semacam kepercayaan, kemauan serta hasrat) dan bisa dimengerti pada perihal pemrosesan informasi. Sedangkan pemrosesan informasi didefinisikan sebagai teori kognitif yang mencerminkan proses penerimaan, pengelolaan, penyimpanan, dan pemanggilan kembali informasi dari pikiran manusia (Slavin, 2006). Bagan pemrosesan informasi menurut Slavin (2006) dapat dilihat pada Gambar 1.

Fauziyah (2020) menjelaskan aktivitas pemrosesan informasi sebagai berikut, (1) menerima informasi adalah aktivitas mental dalam mendapatkan informasi tertentu dari lingkungan sekitarnya, (2) mengolah informasi adalah aktivitas mental dalam mengorganisasi informasi yang diterima sesuai dengan kebutuhan, (3) menyimpan informasi adalah aktivitas mental mempertahankan informasi yang diterima dan mempertahankan pengetahuan dalam memori jangka pendek maupun memori jangka panjang, dan (4) memanggil kembali informasi adalah aktivitas mental dalam mengungkap kembali informasi yang disimpan dalam memori jangka pendek maupun jangka panjang. Dari pendapat tersebut, proses kognitif yang dimaksud adalah aktivitas mental siswa dalam pemrosesan informasi. Pemrosesan informasi yang dimaksud, yaitu menerima informasi, mengolah informasi, menyimpan informasi, dan memanggil kembali informasi.

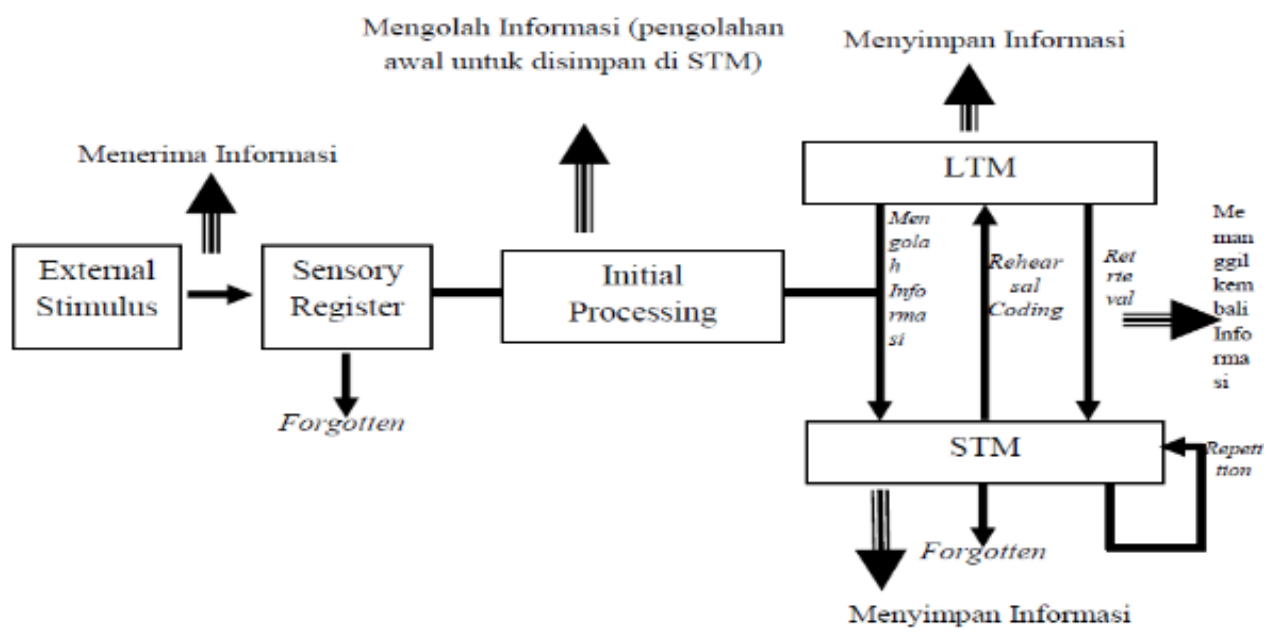

Gambar 1. Teori Pemrosesan Informasi 
Setiap individu yang mengalami proses kognitif akan melalui tahapan menerima informasi. Jika informasi yang diterima berupa masalah yang harus diselesaikan, maka tingkat kognitif akan semakin tinggi karena proses yang dilakukan, digunakan sebagai dasar pengambilan keputusan dalam menyelesaikan masalah (Fauziyah et al., 2020).

Ormrod (2016) mendefinisikan penyelesaian masalah, yaitu penggunaan pengetahuan dan keterampilan yang sebelumnya telah dipelajari, lalu mentransfernya untuk menjawab pertanyaan yang tidak terjawab atau situasi yang sulit. Lebih lanjut Isroil, et al. (2017) menjelaskan penyelesaian masalah, yaitu usaha menemukan solusi atau jawaban dari masalah yang diberikan dengan menggunakan pengetahuan atau konsep matematika yang telah dimiliki sebelumnya. Artinya siswa yang menjawab pertanyaan atau situasi yang sulit setidaknya telah memiliki pengetahuan yang telah dipelajarinya, dalam hal ini siswa tersebut memanggil kembali informasi dalam penyimpanan memori jangka panjangnya untuk menjawab pertanyaan atau situasi yang sulit tersebut. (Polya, 1973) mengusulkan langkah penyelesaian masalah yang sangat bergantung pada aktivitas mental sadar dan terkontrol, yaitu memahami masalah, menyusun rencana, melaksanakan rencana, dan memeriksa kembali.

Penyelesaian masalah harus dijadikan fokus dalam pembelajaran matematika karena penyelesaian masalah merupakan keterampilan yang penting dalam kehidupan sehari-hari dan berguna bagi siswa dalam memperoleh cara berpikir, memunculkan rasa ingin tahu yang terus menerus, dan siswa juga dapat melatih percaya dirinya dalam menyelesaikan masalah matematika di kehidupan sehari-hari. Siswa dapat memperkuat dan memperluas pengetahuannya atau dapat merangsang pembelajaran baru dengan cara menyelesaikan masalah (NCTM, 2000).

Dari beberapa pernyataan di atas, penyelesaian masalah yang dimaksud adalah penggunaan pengetahuan dan keterampilan yang sebelumnya telah dimiliki untuk menemukan solusi atau jawaban dari masalah yang diberikan.

Faktor afektif dan kognitif merupakan faktor yang mempengaruhi pemecahan masalah (Montague, 1997). Faktor afektif mencakup watak perilaku seperti perasaan, minat, sikap, emosi, atau nilai. Kecemasan matematika merupakan salah satu masalah yang masuk ke dalam ranah afektif (Bessant, 1995).

Kecemasan matematika dapat diartikan sebagai emosi negatif yang menghalangi pemecahan masalah matematika. Hal ini lebih dari sekedar tidak menyukai matematika dan mengarah ke penghindaran kelas matematika dan menghindari situasi dimana matematika akan diperlukan (Sparks, 2011). Kecemasan matematika juga melibatkan rasa tegang dan cemas pada siswa ketika menyelesaikan soal matematika dalam kehidupan nyata maupun di akademik (Richardson \& Suinn, 1972). Lebih lanjut Sheffield et al. (2006) mendefinisikan kecemasan matematika sebagai perasaan cemas yang dialami individu ketika menyelesaikan soal matematika.

Kecemasan matematika sendiri terbagi menjadi dua, yaitu kecemasan 
matematika tingkat tinggi dan kecemasan matematika tingkat rendah (Mahmood \& Khatoon, 2011). Pertanyaan yang termuat di dalam Mathematics Anxiety Scale (MAS) dimaksudkan untuk mengidentifikasi efek positif (misalnya perasaan nyaman, suka, gembira, dan senang) dan efek negatif (misalnya perasaan gugup dan khawatir) terhadap matematika dari 14 item dengan 7 item berupa pernyataan positif dan 7 item berupa pernyataan negatif. Siswa yang mendapat skor: $14 \leq x<42$ dalam mengisi pertanyaan pada angket kecemasan dikategorikan siswa berkecemasan rendah, sedangkan siswa yang mendapat skor $42 \leq x \leq 70$ dikategorikan siswa berkecemasan matematika tinggi.

Kecemasan matematika yang dimaksud dalam penelitian ini adalah rasa tegang dan cemas pada siswa ketika menyelesaikan soal matematika dalam kehidupan nyata maupun di akademik. Tingkat kecemasan matematika yang digunakan dalam penelitian ini adalah kecemasan matematika tinggi dan kecemasan matematika rendah.

Motivasi, kecemasan matematika, dan sikap terhadap matematika merupakan faktor penting dalam prestasi matematika (Smetackova, 2015). Siswa yang dapat memahami pola bilangan memiliki dampak positif pada pencapaian hasil belajar matematika di tingkat selanjutnya (Papic, 2013). Maka dari itu materi pola bilangan memiliki dampak yang penting terhadap kecemasan matematika siswa dan prestasi matematika.

Berdasarkan uraian di atas, mengetahui proses kognitif siswa dalam menyelesaikan masalah pada materi pola bilangan ditinjau dari kecemasan matematika dapat menjadi salah kegiatan yang perlu guru matematika kuasai, agar guru matematika dapat menyusun metode pembelajaran yang sesuai untuk mengurangi kecemasan matematika siswa, sehingga siswa dapat meningkatkan kemampuan berpikir pada matapelajaran matematika di tingkat yang lebih tinggi. Maka dari itu, peneliti tertarik untuk melakukan penelitian dengan judul "Proses Kognitif Siswa dalam Menyelesaikan Masalah Pada Materi Pola Bilangan Ditinjau Dari Kecemasan Matematika".

\section{METODE PENELITIAN}

Penelitian deskriptif kualitatif ini bertujuan untuk mendeskripsikan proses kognitif siswa dalam menyelesaikan masalah pada materi pola bilangan ditinjau dari tingkat kecemasan matematika siswa. Sumber data dari penelitian ini adalah siswa kelas VIII SMP Negeri 1 Pamekasan berjumlah 30 yang telah menerima materi pola bilangan. Instrumen utama dalam penelitian ini adalah peneliti. Instrumen pendukungnya terdapat empat jenis yaitu tes kemampuan matematika (TKM) untuk mengontrol dari tingkat kemampuan siswa, angket kecemasan matematika (AKM) yang digunakan untuk memperoleh subjek penelitian, tes penyelesaian masalah (TPM) materi pola bilangan yang digunakan untuk mendeskripsikan proses kognitif siswa dalam menyelesaikan masalah pola bilangan, pedoman wawancara untuk menggali, mendapatkan, dan memperjelas informasi lebih lanjut yang berkaitan dengan hasil tes penyelesaian masalah, dan alasan siswa yang tidak dapat diperoleh dari hasil tes tersebut. 
Semua siswa kelas VIII C SMPN 1 Pamekasan yang terdiri dari 21 siswa laki-laki dan 9 perempuan diminta untuk mengisi AKM. Data hasil AKM dianalisis dengan menghitung skor total dari hasil pengisian angket kecemasan. Dari skor total tersebut peneliti mengelompokkan siswa sesuai dengan tingkat kecemasannya. Kemudian siswa dipilah menjadi kelompok subjek berkecemasan matematika tinggi dan rendah. Selanjutnya kelompok tersebut diminta untuk mengerjakan TKM.
Data dari hasil tes kemampuan matematika dianalisis dengan mengategorikan kemampuan matematika siswa, selanjutnya siswa yang dipilih sebagai subjek adalah siswa dengan kemampuan matematika tinggi karena siswa dengan kemampuan matematika tinggi dapat menyelesaikan soal kategori pemecahan masalah dengan benar, hal tersebut sesuai dengan hasil penelitian Isroil et al. (2017), yang menjelaskan bahwa siswa dengan kemampuan matematika tinggi dapat menyelesaikan masalah matemati-

Tabel 1. Indikator Proses Kognitif Siswa dalam Menyelesaikan Masalah

\begin{tabular}{|c|c|c|c|}
\hline $\begin{array}{c}\text { Tahap Penyelesaian } \\
\text { Masalah } \\
\end{array}$ & Proses Kognitif & Indikator & Kode \\
\hline \multirow[t]{4}{*}{ Memahami Masalah } & Menerima informasi & $\begin{array}{l}\text { Mengamati dan membaca kalimat } \\
\text { dalam soal. }\end{array}$ & A1 \\
\hline & Mengolah informasi & $\begin{array}{l}\text { Menentukan yang diketahui dan } \\
\text { ditanya }\end{array}$ & B1 \\
\hline & \multirow{2}{*}{$\begin{array}{l}\text { Menyimpan dan } \\
\text { Memanggil kembali } \\
\text { informasi }\end{array}$} & $\begin{array}{l}\text { Mengungkapkan isi soal dengan } \\
\text { menggunakan bahasa sendiri }\end{array}$ & $\mathrm{C} 1, \mathrm{D} 1$ \\
\hline & & $\begin{array}{l}\text { Mengaitkan informasi baru dengan } \\
\text { pengetahuan yang dimilikinya } \\
\text { untuk memahami masalah }\end{array}$ & \\
\hline \multirow[t]{2}{*}{ Menyusun Rencana } & Mengolah Informasi & $\begin{array}{l}\text { Menyusun rencana penyelesaian } \\
\text { masalah }\end{array}$ & B2 \\
\hline & $\begin{array}{l}\text { Menyimpan dan } \\
\text { Memanggil Kembali } \\
\text { Informasi }\end{array}$ & $\begin{array}{l}\text { Menggunakan pengetahuan yang } \\
\text { telah dimiliki dan relevan dengan } \\
\text { permasalahan dalam merencanakan } \\
\text { penyelesaian masalah }\end{array}$ & $\mathrm{C} 2, \mathrm{D} 2$ \\
\hline \multirow[t]{2}{*}{$\begin{array}{l}\text { Melaksanakan } \\
\text { Rencana }\end{array}$} & Mengolah Informasi & $\begin{array}{l}\text { Menuliskan langkah-langkah } \\
\text { penyelesaian soal dengan rencana } \\
\text { yang telah disusun }\end{array}$ & B3 \\
\hline & $\begin{array}{l}\text { Menyimpan dan } \\
\text { Memanggil Kembali } \\
\text { Informasi }\end{array}$ & $\begin{array}{l}\text { Menggunakan pengetahuan yang } \\
\text { telah dimiliki dan relevan dengan } \\
\text { permasalahan untuk menyelesaikan } \\
\text { masalah }\end{array}$ & $\mathrm{C} 3, \mathrm{D} 3$ \\
\hline \multirow[t]{2}{*}{ Memeriksa Kembali } & Mengolah informasi & $\begin{array}{l}\text { Memeriksa kebenaran solusi yang } \\
\text { diperoleh }\end{array}$ & B4 \\
\hline & $\begin{array}{l}\text { Menyimpan dan } \\
\text { Memanggil kembali } \\
\text { informasi }\end{array}$ & $\begin{array}{l}\text { Menggunakan pengetahuan yang } \\
\text { dimilikinya ketika memeriksa } \\
\text { kebenaran solusi yang diperoleh. }\end{array}$ & C4, D4 \\
\hline
\end{tabular}


ka dengan benar menggunakan pengetahuan yang dimilikinya. Hasil penelitian (Lestari \& Wijayanti, 2013) menjelaskan bahwa siswa berjenis kelamin laki-laki dan perempuan berkemampuan matematika tinggi memiliki kemampuan yang sama dalam melalui tahapan penyelesaian masalah, yaitu dapat menyelesaikan masalah dan melalui semua tahapannya dengan benar, berbeda dengan tingkat kemampuan rendah baik laki-laki maupun perempuan yang tidak melalui satu tahapan atau lebih dalam menyelesaikan masalah. Sehingga dalam penelitian ini subjek dikontrol dari kemampuan matematika tinggi dengan jenis kelamin sama.

Subjek dalam penelitian ini terdiri dari 2 siswa berkemampuan matematika tinggi dan berjenis kelamin sama, diantaranya 1 siswa memiliki kecemasan matematika tinggi dan 1 siswa memiliki kecemasan matematika rendah. Data hasil wawancara dan TPM dianalisis dengan mengoreksi hasil TPM berdasarkan alternatif jawaban yang telah dibuat serta menyesuaikan TPM berdasarkan indikator proses kognitif dalam menyelesaikan masalah yang dicapai dan dengan memutar kembali rekaman wawancara, mentranskip hasil wawancara, merangkum dan memilih data yang penting, dan mencocokan dengan jawaban yang telah diselesaikan oleh siswa. Terdapat tiga tahapan dalam analisis wawancara yaitu: (1) mereduksi data, (2) penyajian data, dan (3) penarikan kesimpulan.

\section{HASIL DAN PEMBAHASAN}

Berdasarkan hasil AKM, mengidentifikasi bahwa 16 siswa berkecemas- an matematika tinggi dan 14 siswa berkecemasan matematika rendah. Hasil TKM mengidentifikasi 2 siswa berkemampuan matematika tinggi, 14 siswa berkemampuan matematika sedang, dan 14 siswa berkemampuan rendah. Selanjutnya subjek dipilih dengan sepersetujuan siswa, yaitu 1 siswa lakilaki berkemampuan matematika tinggi dan berkecemasan matematika tinggi (ST) dan 1 siswa laki-laki berkemampuan matematika tinggi dan berkecemasan matematika rendah (SR).

Tabel 2. Skor Angket dan Kategori Kecamasan

\begin{tabular}{cccc}
\multicolumn{4}{c}{ Matematika Subjek } \\
\hline \multirow{3}{*}{ No } & Nama & Skor & Kategori \\
& Inisial & Kecemasan & Kecemasan \\
& Subjek & Matematika & Matematika \\
\hline 1. & ST & 46 & Tinggi \\
2. & SR & 39 & Rendah \\
\hline
\end{tabular}

Berikut akan dipaparkan hasil analisis dan pembahasan proses kognitif siswa dalam menyelesaikan masalah pada materi pola bilangan ditinjau dari kecemasan matematika.

\section{Proses Kognitif Subjek dengan Kece- masan Matematika Tinggi Tahap Memahami Masalah}

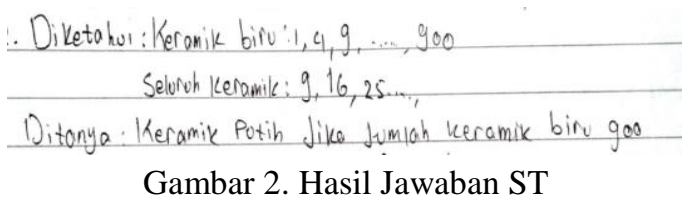

Menerima Informasi (A1)

ST dapat menerima informasi dengan mengamati soal dengan mengarahkan pandangannya ke soal dan membaca soal hingga suaranya terdengar walaupun tidak begitu jelas. 


\section{Mengolah Informasi (B1)}

Dari informasi yang diterima, berdasar Gambar 2 ST mengolah informasi dengan menulis dan menyebutkan hal yang diketahui dengan baik, yaitu pola keramik biru dan pola seluruh keramik. Hasil tersebut sejalan dengan hasil penelitian Ningsih (2016), yang meyatakan subjek berkecemasan matematika tinggi bisa menulis dan menyebutkan hal yang diketahui dengan benar, sehingga merasa subjek sudah cukup untuk untuk menjawab. ST juga mengolah informasi dengan menulis dan menyebutkan hal yang ditanya dengan benar, yaitu berapa keramik putih jika jumlah kermik biru 900.

Menyimpan (Cla) dan Memanggil (Dla) Kembali Informasi

ST menyimpan dan memanggil kembali informasi pada memori jangka pendeknya dengan mengungkapkan isi soal walaupun hal yang diungkapkan sama dengan soal diberikan.

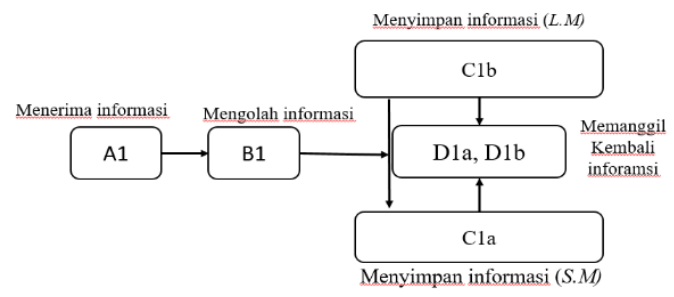

Gambar 3. Skema Proses Kognitif ST pada

Tahap Memahami Masalah

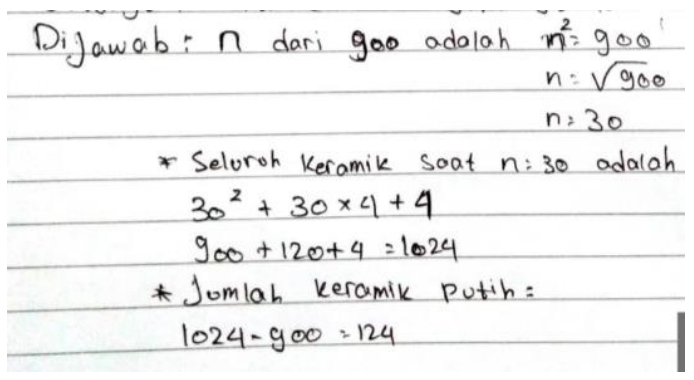

Gambar 4. Hasil Jawaban ST
Menyimpan (Clb) dan Memanggil (D1b) Kembali Informasi

ST juga menyimpan dan memanggil informasi pada memori jangka panjangnya dengan mengaitkan materi yang berhubungan dengan soal yaitu pola bilangan, bangun datar, dan operasi bilangan serta menjelaskan alasan mengaitkan materi tersebut.

Proses Kognitif Subjek dengan Kecemasan Matematika Tinggi Tahap Menyusun Rencana

Mengolah Informasi (B2)

Berdasrkan Gambar 4, ST mengolah informasi yang diterimanya pada tahap memahami masalah dengan menggunakan pola keramik untuk menentukan model keramik ke- $n$ dengan mengakarkan jumlah keramik biru ke- $n$.

ST juga menggunakan pola keramik untuk menentukan jumlah keramik total ke- $n$, namun dalam hal ini ST tidak menuliskan rumus umumnya melainkan langsung menuliskan angkaangka yang akan digunakan untuk mencari banyak keramik putih saat keramik biru berjumlah 900. Ketika ditanya alasannya, ST menjelaskan bagaimana cara memperoleh angkaangka tersebut, yaitu ST menentukan banyaknya keramik putih model ke-30 = $30^{2}+30 \times 4+4$, dengan $30^{2}$ merupakan banyaknya keramik biru dan menjelaskan bahwa model ke-30 merupakan akar dari banyaknya keramik biru (900), $30 \times 4$ diperoleh dari banyak keramik putih yang sejajar dengan sisi keramik biru dalam gambar tersebut terdapat 4 sisi yang sejajar, dan 4 diperoleh dari sisa keramik putih yang tidak sejajar dengan keramik biru yang 
berada di bagian pojok keramik putih. Cara tersebut ST dapatkan dengan menggeneralisasi pola pada model ke 1 , 2, dan 3. Setelah itu ST menentukan rumus banyaknya keramik putih, yaitu mengu-rangi banyak keramik total ke- $n$ dengan banyak keramik biru ke- $n$.

\section{Menyimpan (C2) dan Memanggil (D2)} Kembali Informasi

ST menyimpan dan memanggil kembali informasi dengan menentukan rumus banyak keramik total dan rumus banyak keramik putih pada model ke-n dalam menyusun rencana dengan baik menggunakan informasi yang didapat dari tahap memahami masalah, namun dalam menjelaskan rencananya ST kesusahan dan merasa tidak percaya diri, hal ini dapat diketahui ketika peneliti bertanya, "bagaimana kamu mendapatkan cara untuk menentukan keramik putih itu, dek?", dan ST hanya terdiam dan mengatakan setelah beberapa waktu kemudian, "saya tau, tapi saya tidak bisa jika diminta untuk menjelaskan". Maka dari itu peneliti memberi pertanyaanpertanyaan stimulus untuk mengetahui bagaimana cara ST mendapatkan langkah-langkah tersebut, sehingga ST dapat menjelaskannya. Hal ini sejalan dengan Syafri (2017), yang menyatakan bahwa secara umum seseorang yang memiliki kecemasan matematika terkait dengan kurangnya kepercayaan orang itu terhadap matematika.

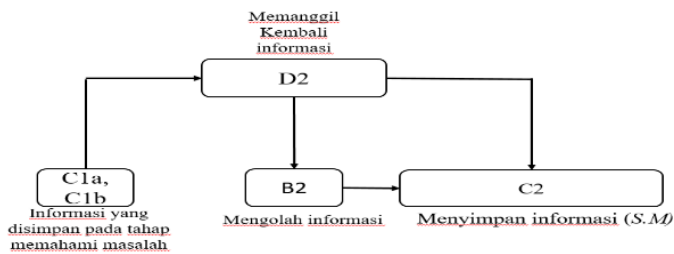

Gambar 5. Skema Proses Kognitif ST pada Tahap Menyusun Rencana
Proses Kognitif Subjek dengan Kecemasan Matematika Tinggi Tahap Melaksanakan Rencana

Mengolah Informasi (B3)

Berdasar Gambar 4, ST menentukan nilai $n=30$ dari akar banyak keramik biru (900) pada model ke-30. Setelah itu ST menentukan jumlah keramik total pada model ke-30 dengan rumus yang diperolehnya pada tahap menyusun rencana, yaitu jumlah keramik total $=$ $30^{2}+30 \times 4+4=1024$. Setelah itu ST menentukan jumlah keramik putih ke-30, yaitu mengurangkan jumlah keramik total pada model ke-30 dengan jumlah keramik biru pada model ke-30, yaitu $1024-900=124$ keramik putih.

Menyimpan (C3) dan Memanggil (D3) Kembali Informasi

ST menyimpan dan memanggil kembali informasi dalam melaksanakan rencana dengan menggunakan rumus banyak keramik total dan rumus banyak keramik putih yang didapat dari tahap menyusun rencana dengan baik dan benar. Hal ini sejalan dengan hasil penelitian Ismawati et al. (2015), yang menjelaskan bahwa siswa dengan kecemasan matematika tinggi mampu menggunakan langkah-langkah pemecahan masalah yang telah direncanakan dengan benar.

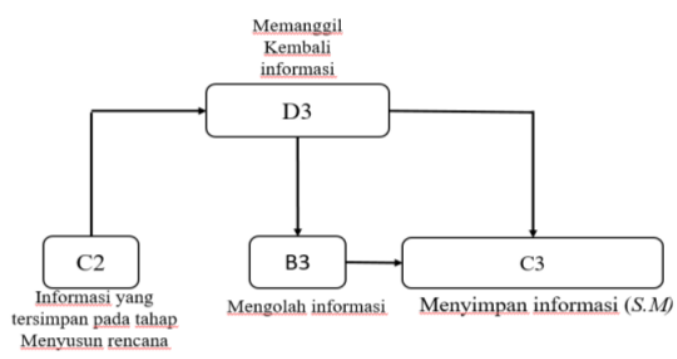

Gambar 6. Skema Proses Kognitif ST pada Tahap Melaksanakan Rencana 
Proses Kognitif Subjek dengan Kecemasan Matematika Tinggi Tahap Memeriksa Kembali

Mengolah Informasi (B4)

ST tidak mengolah informasi pada tahap memeriksa kembali karena dia telah yakin hasilnya sudah benar, sehingga ST tidak mengecek kembali jawabannya. Hal ini sejalan dengan hasil penelitian Ningsih (2016) yang menjelaskan bahwa siswa yang memiliki kecemasan matematika tinggi tidak menggunakan cara lain untuk memeriksanya dan cenderung mengatakan sudah yakin dan benar.

Menyimpan (C4) dan Memanggil (D4) Kembali Informasi

ST menyimpan dan memanggil kembali informasi yang didapat dari tahap melaksanakan rencana, yaitu dengan menyimpulkan hasil jawaban dengan baik dan benar dengan mengatakan, "kesimpulan dari jawabannya yaitu, banyak keramik putih yang dibutuhkan adalah 124 jika keramik birunya 900".

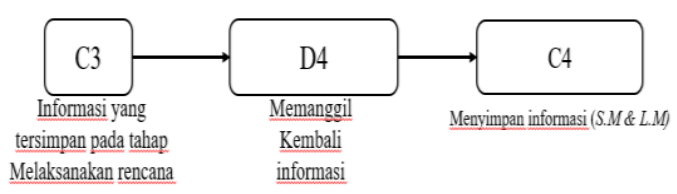

Gambar 7. Skema Proses Kognitif ST pada Tahap Memeriksa Kembali

\section{Proses Kognitif Subjek dengan Kece- masan Matematika Rendah Tahap Memahami Masalah}

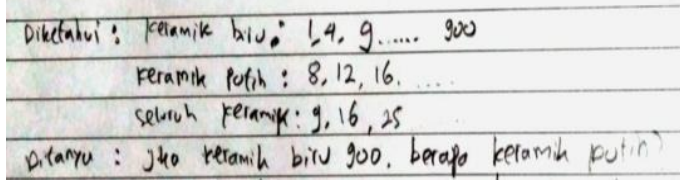

Gambar 8. Hasil Jawaban SR

\section{Menerima Informasi (A1)}

SR dapat menerima informasi dengan mengamati dan membaca soal tanpa mengeluarkan suara. Hal ini sejalan dengan hasil penelitian Ismawati et al. (2015), yang menjelaskan bahwa siswa berkcemasan matematika rendah berusaha membaca masalah dengan berdiam cukup lama.

\section{Mengolah Informasi (B1)}

Dari informasi yang didapatkan, SR dapat mengolah informasi dengan menulis dan menyebutkan hal yang diketahui dengan baik, yaitu pola keramik biru, pola keramik putih, dan pola seluruh keramik. SR juga dapat menyebutkan hal yang ditanya sesuai dengan informasi yang ditanyakan pada soal, yaitu jika keramik biru 900, berapa keramik putih. Hal ini sejalan dengan hasil penelitian Ismawati et al. (2015) yang menjelaskan bahwa siswa berkecemasan matematika rendah dapat menentukan apa yang diketahui dan ditanya dengan tepat tanpa mengalami kesulitan.

Menyimpan (C1a) dan Memanggil (Dla) Kembali Informasi

SR menyimpan dan memanggil kembali informasi dengan mengungkapkan isi soal menggunakan bahasanya sendiri dengan hanya melihat pola keramiknya saja.

Menyimpan (C1b) dan Memanggil (D1b) Kembali Informasi

SR juga menyimpan dan memanggil kembali informasi dengan mengaitkan materi yang berhubungan dengan soal yaitu pola bilangan dan 
persegi serta menjelaskan alasan mengaitkan materi tersebut.

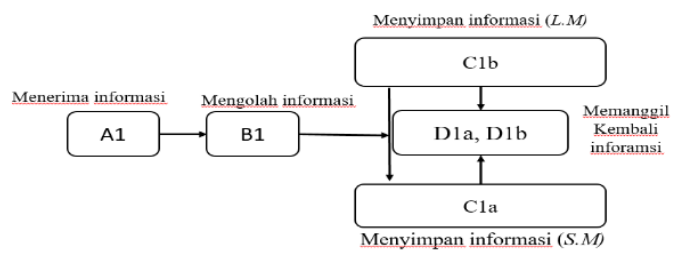

Gambar 9. Skema Proses Kognitif SR pada Tahap Memahami Masalah

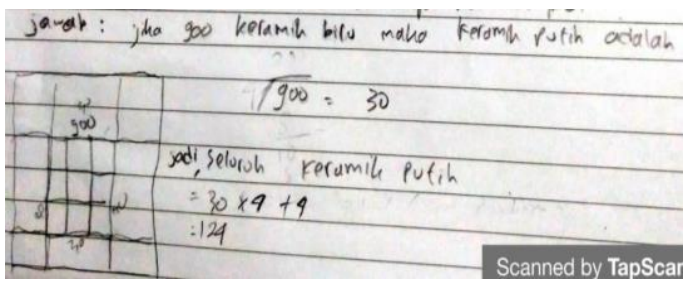

Gambar 10. Hasil Jawaban SR

Tabel 3. Hasil Wawancara Peneliti dengan SR

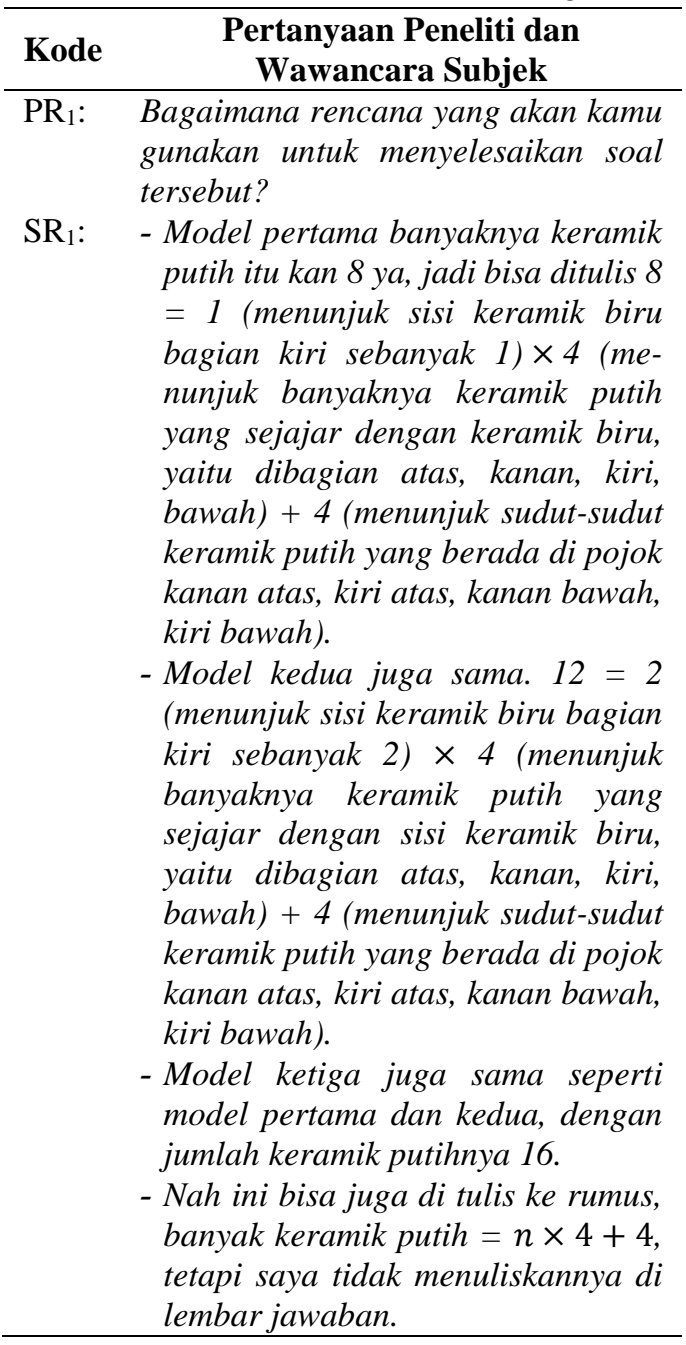

\section{Proses Kognitif Subjek dengan Kece- masan Matematika Rendah Tahap Menyusun Rencana}

Mengolah Informasi (B2)

Berdasar Gambar 10 dan Tabel 3, pada tahap ini SR menentukan rumus banyaknya keramik putih model ke-30, dengan 30 merupakan akar dari banyaknya keramik biru (900) model ke30. SR mendapatkan rumus tersebut dengan menggeneralisasi dari pola yang diketahui, walaupun SR tidak menuliskan, namun SR mengungkapkan hal tersebut saat wawancara. Hal ini sejalan dengan hasil penelitian Ningsih (2016) yang menjelaskan bahwa siswa berkecemasan matematika tingkat rendah, mampu untuk merencanakan penyelesaian dengan menggunakan materi yang telah dimilikinya.

Menyimpan (C2) dan Memanggil (D2) Kembali Informasi

SR menyimpan dan memanggil kembali informasi dalam memori jangka pendek yang diterimanya pada tahap memahami masalah untuk menyusun rencana, yaitu menentukan rumus banyaknya kermaik putih pada model ke- $n$ atau ke-30.

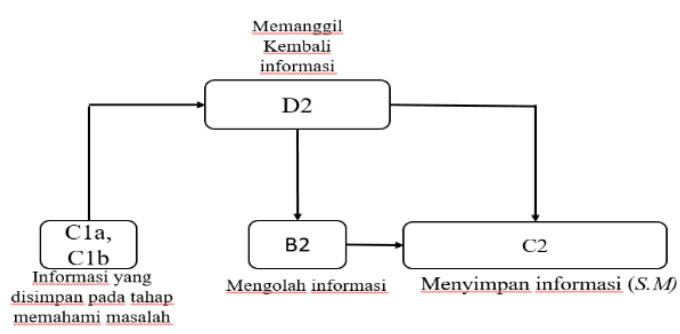

Gambar 11. Skema Proses Kognitif SR pada Tahap Menyusun Rencana 
Proses Kognitif Subjek dengan Kecemasan Matematika Rendah Tahap Melaksanakan Rencana

Mengolah Informasi (B3)

Berdasarkan Gambar 10, SR menentukan nilai $n$ dengan mengakarkan banyak keramik biru pada model ke-30, lalu SR menentukan banyak keramik putih pada model ke- $n$.

Menyimpan (C3) dan Memanggil (D3) Kembali Informasi

SR menyimpan dan memanggil kembali informasi dalam melaksanakan rencana dengan menggunakan rumus banyaknya keramik putih model ke- $n$ yang didapat dari tahap menyusun rencana untuk menentukan banyak keramik putih pada model ke- $n$. Hal ini sejalan dengan pendapat Wicaksono (2013) yang menjelaskan bahwa siswa yang kurang cemas mampu menggunakan kecemasannya dalam mengatasi atau menyelesaikan masalah matematika.

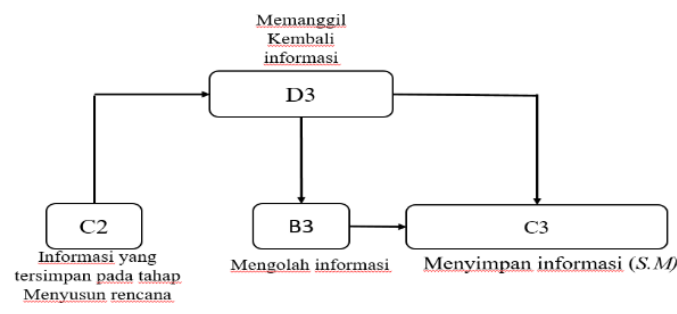

Gambar 12. Skema Proses Kognitif SR pada Tahap Melaksanakan Rencana

Proses Kognitif Subjek dengan Kecemasan Matematika Rendah Tahap Memeriksa Kembali

\section{Mengolah Informasi (B1)}

Berdasarkan Tabel 4, SR menggunakan pola keramik putih dan menggunakan cara lain untuk memeriksa kembali jawabannya, yaitu rumus barisan aritmatika untuk meyakinkan jawabannya benar, hasil yang diperoleh sama dengan hasil awal.

Tabel 4. Hasil Wawancara Peneliti dengan SR

\begin{tabular}{|c|c|}
\hline Kode & $\begin{array}{l}\text { Pertanyaan Peneliti dan } \\
\text { Wawancara Subjek }\end{array}$ \\
\hline $\mathrm{PR}_{2}$ : & $\begin{array}{l}\text { Bagaimana kamu meyakinkan bahwa } \\
\text { jawabanmu benar? }\end{array}$ \\
\hline $\mathrm{SR}_{2}$ : & $\begin{array}{l}\text { Saya bisa pake rumus lain yaitu } \\
\text { menggunakan pola barisan Un }=a+ \\
(n-1) b \text { tetapi menggunakan pola } \\
\text { lainnya, yaitu pola keramik putih } 8 \text {, } \\
12,16, \ldots . \text { Dengan a }(\text { suku awal })=8, \\
b(\text { beda })=4 \text {, dan suku ke- } n=30 \text { yang } \\
\text { sebelumnya udah ditentuin. Sehingga } \\
U_{30}=8+(29) 4=124 .\end{array}$ \\
\hline
\end{tabular}

Menyimpan (C4a) dan Memanggil (D4a) Kembali Informasi

SR menyimpan dan memanggil kembali informasi yang terdapat dalam memori jangka panjangnya untuk memeriksa jawabannya dengan baik dan benar. Hal ini sejalan dengan hasil penelitian Ningsih (2016) yang menjelaskan bahwa siswa berkecemasan matematika tingkat rendah mampu menyebutkan alternatif lain dalam menyelesaikan masalah matematika.

Menyimpan (C4b) dan Memanggil (D4b) Kembali Informasi

SR juga menyimpan dan memanggil kembali informasi yang didapat dari tahap melaksanakan rencana dengan menyimpulkan hasil pekerjaannya dengan baik dan benar dengan mengatakan, "banyak keramik putih yang dibutuhkan untuk membuat model keramik jika keramik birunya 900 adalah 124 keramik putih". Hal ini sejalan dengan hasil penelitian Ismawati et al. (2015) yang menjelaskan bahwa siswa berkecemasan matematika rendah memeriksa kembali semua jawaban yang diperoleh dengan cara meneliti atau mengecek jawabannya. 


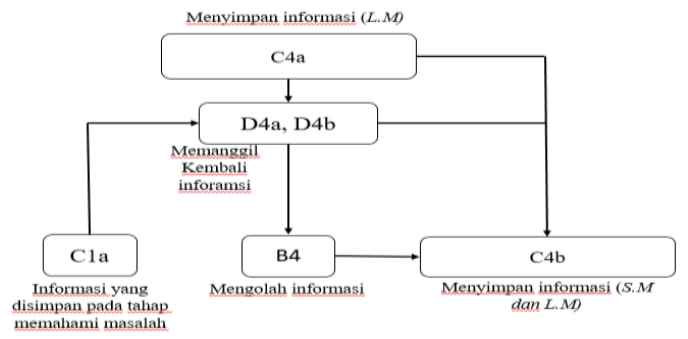

Gambar 13. Skema Proses Kognitif SR pada Tahap Memeriksa Kembali

Berdasarkan hasil dan pembahasan di atas, Tabel 5 memaparkan perbedaan proses kognitif subjek berkecemasan matematika tinggi dan rendah dengan kemampuan matematika tinggi.

\section{PENUTUP}

Hasil penelitian dan pembahasan menunjukkan bahwa siswa berkecemasan matematika tinggi dan rendah dengan kemampuan tinggi dapat menyelesaikan masalah pada materi pola bilangan, namun pada proses kognitifnya terdapat perbedaan dalam menerima, mengolah, menyimpan, dan memanggil kembali informasi. Siswa berkecemasan matematika tinggi pada tahap menyusun rencana dalam menyimpan dan memanggil kembali informasi sedikit kesusahan dan tidak percaya diri untuk menyampaikan hasil jawabannya, sedangkan siswa berkecemasan matematika rendah dapat menjelaskan dengan dengan percaya diri. Pada tahap memeriksa kembali, siswa berkecemasan matematika rendah dapat memeriksa kembali hasil jawabannya dengan menggunakan cara yang lain, sedangkan siswa berkecemasan matematika tinggi tidak melakukannya.

Sehingga disarankan untuk guru matematika khususnya jenjang SMP kelas VIII untuk menyusun metode pembelajaran yang dapat menurunkan tingkat kecemasan matematika siswa, supaya siswa dapat meningkatkan kemampuan kognitifnya pada mata pelajaran matematika di tingkat yang lebih tinggi dengan kecemasan matematika yang rendah.

Tabel 5. Perbedaan Proses Kognitif Subjek Berkecemasan Matematika Tinggi dan Rendah dengan Kemampuan Matematika Tinggi

\begin{tabular}{|c|c|c|}
\hline \multirow{2}{*}{ Langkah Penyelesaian } & \multicolumn{2}{|c|}{ Subjek Berkecemasan } \\
\hline & Tinggi & Rendah \\
\hline \multirow[t]{2}{*}{ Memahami Masalah } & $\begin{array}{l}\text { Menerima informasi dengan } \\
\text { mengamati dan membaca soal } \\
\text { hingga suaranya terdengar }\end{array}$ & $\begin{array}{l}\text { Menerima informasi dengan } \\
\text { mengamati dan memabca } \\
\text { soal tanpa mengeluarkan } \\
\text { suara }\end{array}$ \\
\hline & $\begin{array}{l}\text { Menyimpan dan memanggil } \\
\text { kembali informasi dengan } \\
\text { membaca soal sama persis dengan } \\
\text { soal yang diberikan oleh peneliti }\end{array}$ & $\begin{array}{l}\text { Menyimpan dan memanggil } \\
\text { kembali informasi dengan } \\
\text { membaca soal menggunakan } \\
\text { kalimatnya sendiri }\end{array}$ \\
\hline Menyusun Rencana & $\begin{array}{l}\text { Menyimpan dan memanggil } \\
\text { kembali informasi dengan tidak } \\
\text { percaya diri dalam } \\
\text { menjelaskannya }\end{array}$ & $\begin{array}{l}\text { Menyimpan dan memanggil } \\
\text { kembali informasi dengan } \\
\text { percaya diri dalam } \\
\text { menjelaskannya }\end{array}$ \\
\hline Memeriksa Kembali & $\begin{array}{l}\text { Tidak mengolah informasi untuk } \\
\text { memeriksa kembali jawabannya }\end{array}$ & $\begin{array}{l}\text { Mengolah informasi dengan } \\
\text { menggunakan cara lain untuk } \\
\text { memeriksa kembali } \\
\text { jawabannya }\end{array}$ \\
\hline
\end{tabular}




\section{DAFTAR PUSTAKA}

Bessant, K. C. (1995). Factors associated with types of mathematics anxiety in college students. Journal for Research in Mathematics Education, 26(4), 327-345.

Fauziyah, N. (2020). Proses Kognisi Siswa Autism Spectrum Disorder (Asd) Tingkat Sma Dalam Menyelesaikan Masalah Matematika Berdasarkan Perbedaan Tingkat Inteligensi. Disertasi. Surabaya: Universitas Negeri Surabaya.

Fauziyah, N., Budayasa, I. K., \& Juniati, D. (2020). Differences in the Cognitive Processes of Autism Spectrum Disorder Students in Understanding Mathematical Problems Based on the Level of Intelligence. International Journal of Psychosocial Rehabilitation, Vol. 24, Issue 06.

Ismawati, N., Masrukan, \& Junaedi, I. (2015). Strategi Dan Proses Berpikir Dalam Menyelesaikan Soal. Unnes Journal of Mathematics Education Research.

Isroil, A., Budayasa, I. K., \& Masyriah. (2017). Profil Berpikir Siswa Smp Dalam Menyelesaikan Masalah Matematika Ditinjau Dari Kemampuan Matematikajurnal Review Pembelajaran Matematika. JRPM, Vol. 2, No. 2.

Jones, V. O. (2006). Cognitive processes during problem solving of middle school students with different levels of mathematics anxiety and self esteem: case studies. Doctoral Dissertation. Florida State University.

Lailiyah, S., \& et al. (2015). Proses Berpikir Versus Penalaran Matematika. Prosiding Seminar
Nasional Matematika dan Pendidikan Matematika, 10161023.

Lestari, S., \& Wijayanti, P. (2013). Proses Berpikir Kritis Siswa Dalam Memecahkan Masalah Matematika Open Ended Ditinjau Dari Kemampuan Matematika Siswa Dan Perbedaan Jenis Kelamin Pada Materi Kubus Dan Balok. MATHEdunesa, Vol 2, No 3.

Mahmood, S., \& Khatoon, T. (2011). Development and Validation of the Mathematics Anxiety Scale for Secondary and Senior Secondary School Students. British Journal of Arts and Social Sciences, Vol.2 No.2.

Montague, M. (1997). Student perception, mathematical problem solving, and learning disabilities. Remedial and Special Education, 18(1), 46-53.

NCTM. (2000). Principles and Standards for School Mathematics. US: National Council of Teachers of Mathematics.

Ngilawajan, D. A. (2013). Proses Berpikir Siswa Sma Dalam Memecahkan Masalah Matematika Materi Turunanditinjau Dari Gaya Kognitiffield Independentdan Field Dependent. Pedagogia, 7183.

Ningsih, E. V. (2016). Proses Berpikir Mahasiswa Dalam Memecahkan Masalah Aplikasi Integral Ditinjau dari Kecemasan Belajar Matematika (Math Anxiety). Jurnal Iqra'.

Papic, M. (2013). A Mathematics Intervention: The Case of 4 Year- 
old Rylan and Hilda. ProcediaSocial and Behavioral Sciences, Hal. 92-101.

Polya, G. (1973). How to Solve It. Garden City: Doubleday.

Richardson, F. C., \& Suinn, R. M. (1972). The Mathematics Anxiety Rating Scale: Psychometric Data. Journal of Counseling Psychology, 19(6), 551-554.

Sheffield, D., \& Hunt, T. (2006). How does anxiety influence maths performance and what can we do about it?. MSOR connections.

Slavin, R. E. (2006). Educational psychology: Theory and practice (8th edition). Boston: Pearson Education, Inc. Hal. 167.

Smetackova, I. (2015). Gender Stereotypes, Performance and Identification with Math. Procedia Social and Behavioral Sciences, 211-219.

Sparks, S. D. (2011). Researchers Probe Causes of Math Anxiety. Education Week.

Syafri, F. S. (2017). Ada Apa Dengan Kecemasan Matematika ? Journal of Mathematics Education IKIP Veteran, 59-65.

Wicaksono, A. B., \& Saufi, M. (2013). Mengelola Kecemasan Siswa Dalam Pembelajaran Matematika. Prosiding Seminar Nasional Matematika dan Pendidikan Matematika. 